NMT-7 Plan for Producing Certifiable TRU Debris Waste for WIPP

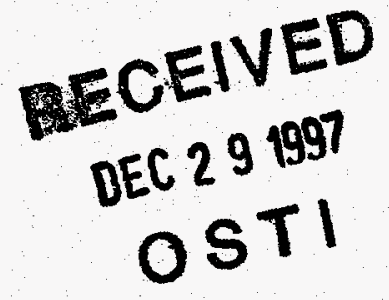

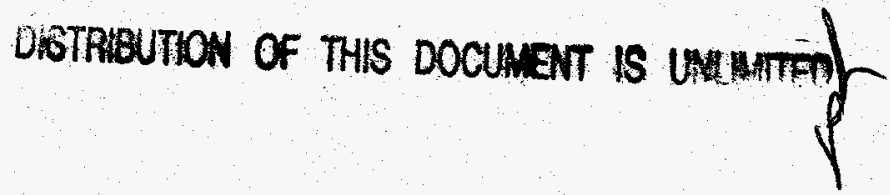

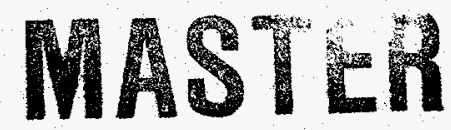

\section{LOS Alamos}

Los Alamos National Laboratory is operated by the University of California for the United States Department of Energy under contract W-7405-ENG-36. 
An Affirmative Action/Equal Opportunity Employer

This report was prepared as an account of work sponsored by an agency of the United States Government. Neither The Regents of the University of California, the United States Government nor any agency thereof, nor any of their employees, makes any warranty, express or implied, or assumes any legal liability or responsibility for the accuracy, completeness, or usefulness of any information, apparatus, product, or process disclosed, or represents that its use would not infringe privately owned rights. Reference herein to any specific commercial product, process, or service by trade name, trademark, manufacturer, or otherwise, does not necessarily constitute or imply its endorsement, recommendation, or favoring by The Regents of the University of California, the United States Government, or any agency thereof. The views and opinions of authors expressed herein do not necessarily state or reflect those of The Regents of the University of California, the United States Government, or any agency thereof. Los Alamos National Laboratory strongly supports academic freedom and a researcher's right to publish; as an institution, however, the Laboratory does not endorse the viewpoint of a publication or guarantee its technical correctness. 


\section{DISCLAIMER}

Portions of this document may be illegible electronic image products. Images are produced from the best available original document. 
NMT-7 Plan for Producing Certifiable

TRU Debris Waste for WIPP

Andrew J. Montoya 


\title{
NMT-7 Plan for Producing Certifiable \\ TRU Debris Waste For WIPP
}

\author{
Andrew J. Montoya
}

\begin{abstract}
Analysis of waste characterization data for debris items generated during a recent six month period indicates that the certifiability of TRUPACT II payload containers packaged at the Los Alamos National Laboratory Plutonium Facility (TA-55) can be increased from approximately $52 \%$ of solid waste payload containers to $78 \%$ by applying the simple strategies of screening out high decay heat items and sorting remaining items to maintain nuclear material loading at levels below WIPP waste acceptance limits. Implementation of these strategies will have negative impacts on waste minimization and waste management operations that must also be considered.
\end{abstract}

\section{Introduction}

NMT-7 has agreed with CST-7 TWCP to produce 500 certifiable TRU debris waste payload containers for shipment to WIPP during fiscal year 1998. LANL has obtained WIPP certification authority for debris TRU waste and must be ready to ship waste to WIPP when it opens (currently scheduled for May 1998). Many debris waste drums generated by NMT cannot be certified for WIPP because they do not meet the TRUPACT II SARP maximum allowed wattage limits for the applicable shipping category. Historically, TRU waste packages have had SNM gram loading which met the LANL discard limits established for TRU waste rather the WIPP determined wattage limits.

At TA-55, debris waste includes metal, glass, leaded gloves, HEPA filters, and miscellaneous combustibles. It does not include cemented liquids, salts, hydroxide cakes, ash, or absorbed oils which are categorized as homogeneous waste streams.

Waste characterized on the NMT Waste Management System is considered "currently generated" and will be managed jointly by NMT-7 and TWCP as specified in the TA-55 Transuranic Waste Interface Document and a memorandum of understanding, pending approval. Waste generated prior to the implementation of the Waste Management System is managed by Environmental Management as "retrievably stored." TWCP is responsible for the certification of retrievably stored waste.

TA-55 generated 12555 -gallon drums and 10 standard waste boxes (SWB) of certifiable TRU debris waste during the one-year period from July 1, 1996 to June 30, 1997. Eighty-five 
uncertifiable drums were produced during the same period. Little load management was used to meet wattage limits. The strategy presented here is based on evaluation of the waste generation for this time period including a detailed analysis of decay heat estimated for waste items categorized by material type contaminants, matrix, and packaging configurations.

\section{Analysis}

Approximately 240 drums and 10 direct load standard waste boxes (SWB) of solid TRU waste have been generated at TA-55 in FY97. This does not include the cemented liquids. The waste generation rate for FY98 was determined by annualizing the rate measured over the last six months. The first two quarters were not typical because of the shutdown of PF-4 during November and December for Operations Center upgrades and were disregarded. There are no clear indications that rates will increase or decrease over the next twelve months. Generation rates for the last two years and a projection for the current year are shown in Table 1.

\begin{tabular}{|lcc|}
\hline & Drums & SWBs \\
FY96 & 298 & 4 \\
FY97 & 240 & 10 \\
FY98 & 260 & 10 \\
\hline
\end{tabular}

Table 1: TA-55 TRU Solid Waste Generation Rate

Approximately eight percent of the waste managed by TRU Solid Waste Operations is categorized as homogeneous (i.e. pyrochemical salts, hydroxide cakes, absorbed oils, and ash) for which LANL has not yet received certification authority. At the current rate over the six most common waste streams, about $52 \%$ of drums and $100 \%$ of SWBs are certifiable. Another $38 \%$ of the drums are not certifiable because they exceed the current heat decay limits and $2 \%$ are from the least common waste streams as shown in Figure 1.

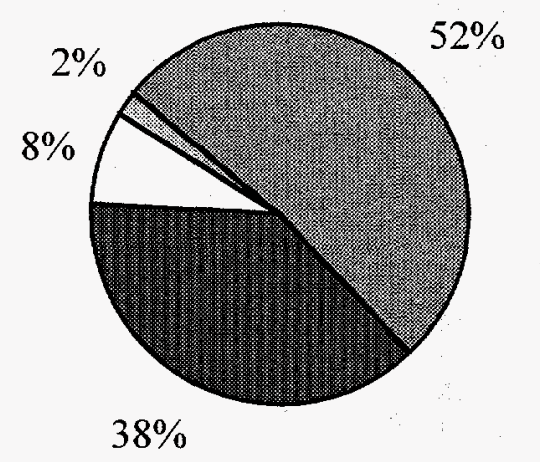

Certifiable

Exceed Decay Heat Limit

DHomogenous

口Uncommon Waste Stream

Fig. 1: FY96/FY97 Certifiability Rate for Solid Wa:

For FY97 TA-55 has generated about 125 certifiable drums and 10 SWBs. In FY96 TA-55 generated a total of almost 300 solid TRU drums. If we assume the above rate, about 150 drums 
are certifiable. In addition, four certifiable SWBs were generated. Assuming that FY98 generation rates will be similar to this year and if no waste management processes are modified, 135 certifiable drums and 10 SWBs will be generated. This exceeds recent estimates of the proportion of currently generated TA-55 debris drums that would be certifiable. This is due entirely to relief provided for TRUPACT II payload heat decay limits by recently approved or proposed revisions to the SARP. The heat decay limits used to estimate certifiability rates here are those calculated for the recent proposed revision of LANL TRUCON Codes as submitted to NRC by WIPP. Those proposed TRUCON Codes take advantage of recently approved allowances for use of filtered confinement layers and the greater diffusivity of drum filters currently in use. In addition, they take advantage of the proposed replacement of Table $5 \mathrm{~B}$ in TRUCON with the use of a worksheet to calculate analytical heat decay limits. This provides for a more precise determination of heat decay limits and greater flexibility in assignment of shipping categories.

\section{Strategy}

The heat decay limit currently proposed for a single filtered confinement layer is $154 \%$ greater than the limit for an unfiltered layer. If the TA-55 waste management process is modified in FY98 so that all debris waste is packaged in no more than one filtered confinement layer, then another 38 drums could be certifiable with no net increase in the number of drums generated. Although this will cause little impact to solid waste operations, more bag changes (a potentially high exposure activity) will be required of waste originators and their groups will have to absorb the additional costs of filtered bags.

Sorting and segregation of waste items during packaging and not allowing the heat decay limit to be exceeded by monitoring the total SNM loading of the payload container, can also be used assure generation of certifiable drums. This process is necessarily accompanied by "volume expansion" as some drums are under loaded to meet the limit. Analysis of currently generated waste streams confirms that some items are individually loaded with SNM near or exceeding the applicable limit. Items near the heat decay limit can be packaged one or two to a drum to be certifiable, but items exceeding the heat decay limit will generate uncertifiable drums whether packaged one per drum or combined to minimize volume. With segregation and combining of "hot" items, other limits (e.g. criticality, plutonium equivalent curies, etc.) must be monitored. For Pu239 contaminated waste sometimes one or two hot items occur in an otherwise compliant drum at a rate of about one in every ten drums. For Pu238 waste streams SNM loading per item covers a wide range from well under to way over the applicable limit. If high heat decay Pu239 items are screened out, low and high heat decay Pu238 items are sorted and segregated for packaging, and near limit items are packaged one and two items to a drum, (see Table 2) approximately 62 more certifiable drums and 40 uncertifiable drums will be generated - a net increase of 42 drums overall. 


\begin{tabular}{|lll|}
\hline \multicolumn{1}{|c|}{ Waste Profile } & \multicolumn{1}{c|}{ Mitigation } & WACLimit \\
$\mathrm{Pu} 239$ waste just over limit & Use filtered bags & \\
$\mathrm{Pu} 239$ waste with "hot spots" & Segregate hot spots one to a drum & Criticality \\
$\mathrm{Pu} 238$ waste & Sort and segregate, "expand volume" & PE Curies \\
\hline
\end{tabular}

Table 2: Strategies for increasing generation rate of certifiable waste

These strategies would increase the proportion of certifiable drums to $78 \%$ of the TA-55 solid TRU waste drums generated in FY98. (see Figure 2). Overall TRU solid waste generation would increase to 302 drums. The total amount of currently generated certifiable waste TA-55 would total approximately 510 drums and 24 direct loaded standard waste boxes (see Table 3).

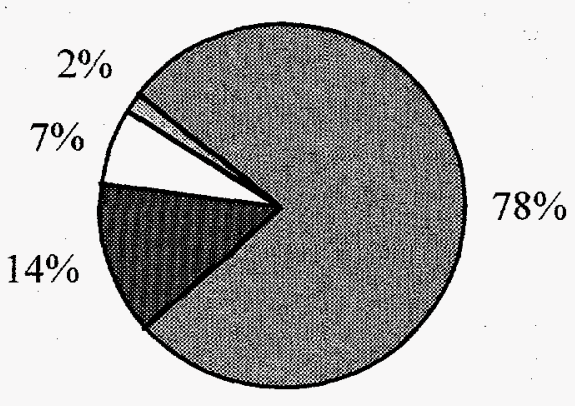

图 Certifiable

Exceed Decay Heat Limit

$\square$ Homogenous

Uncommon Waste Stream

Fig. 2: Projected FY98 Certifiability Rate for Solid Wa:

\begin{tabular}{|lcccc|}
\hline & Certifiable Debris Waste & $\begin{array}{c}\text { Increase in } \\
\text { certifiable drums }\end{array}$ & $\begin{array}{c}\text { Modified Waste } \\
\text { Generation (drums) }\end{array}$ \\
FY96 & Drums & SWBs & & \\
FY97 & 150 & 4 & & \\
FY98 & 125 & 10 & 100 & 302 \\
\hline Total & $\frac{235}{\mathbf{5 1 0}}$ & $\frac{10}{\mathbf{2 4}}$ & & \\
\hline
\end{tabular}

Table 3: Generation Rate for Certifiable TRU debris containers 


\section{Recommendations and Issues}

The following activities must be completed to assure that these drums and SWBs can be certified for TRUPACT II shipment to WIPP:

- Acceptable knowledge documentation must be compiled for the following waste streams as identified in the LANL TRU Waste Characterization Sampling Plan. To expedite this process TWCP would be expected to provide the template for the auditable documentation based on their previous submittal and support interpretation of the QAPP and ad hoc WIPP guidance.

$\diamond \quad$ TA $-55-20$

Nonmixed combustible waste (LA116)

$40 \%$
$40 \%$
$6 \%$
$5 \%$
$4 \%$
$2 \%$

$\checkmark \quad$ TA $-55-22$

Nonmixed metal waste (LA117)

Mixed leaded gloves waste (LA123)

Nonmixed glass waste (LA118)

$5 \%$

$\diamond$ TA-55-24

Nonmixed HEPA filters (LA119)

$4 \%$

$\checkmark$ TA-55-21

Mixed metal waste (LA117)

$2 \%$

- TRUCON Code chemical lists must be evaluated and revised. Currently, the NRC approval is required. NMT-7 will support TWCP in preparing future submittals to WIPP.

Additional debris drums could be made certifiable by documenting AK for other less common waste streams (i.e. nonmixed graphite waste, mixed combustible waste, and mixed glass waste) and testing drums for gas generation as specified in SARP. It is unlikely that these activities can be completed in FY98.

Payload containers that remain uncertifiable despite use of least confining packaging configurations possible, aggressive sorting and segregation, and volume expansion will require storage as uncertifiable. To become certifiable will require additional relief on decay heat limits from matrix depletion studies, approval of hydrogen getter use, approval of ever higher diffusivity filters, approval of mixed shipping category TRUPACT II loading, etc. Formal approval by DOE of interim storage of uncertifiable payload containers should be requested by the highest levels of Laboratory management.

Additional issues impacting certifiability of TA-55 debris waste include the pending results of the gas diffusion study on twist, tie, and tape bag closures and TWCP assay capability for direct loaded SWBs. In addition, confirmation of the number of layers of packaging will be required for some containers closed before July 1,1997 as this is not adequately documented on the TA-55 Waste Management System. 


\section{BIBLIOGRAPHY}

Los Alamos National Laboratory, 1997, Los Alamos National Laboratory Transuranic Waste Characterization Sampling Plan (TWCP-PLAN-1.2.7-001, R.0) (1997).

Los Alamos National Laboratory, 1997, TA-55 Transuranic Waste Interface Document (WMTA55-TWID-R0.1) (1997).

Department of Energy, 1996, TRUPACT-II Content Codes (TRUCON), DOE/WIPP 89-004, Revision 10, Carlsbad, New Mexico, U.S. Department of Energy, Carlsbad Area Office (1996).

Nuclear Regulatory commission, 1996, Safety Analysis Report for the TRUPACT-II Shipping Package, Docket 9218, Washington, D.C., U.S. Nuclear Regulatory Commission (1996).

Nuclear Regulatory commission, 1997, Safety Analysis Report for the TRUPACT-II Shipping Package, Revision 17, Proposed (1997).

Department of Energy, 1996, Waste Acceptance Criteria for the Waste Isolation Pilot Plant (DOE/WIP-069, Revision 5, Carlsbad, New Mexico, U. S. Department of Energy, Carlsbad Area Office (1996). 